\title{
A perspective on the vocabulary common to Classical and Vulgar Latin
}

\author{
George Bogdan Țâra* \\ Faculty of Letters, History and Theology, West University, Bd. Vasile Pârvan 4, 300223 Timişoara, Romania
}

\section{Article info}

History:

Received February 17, 2017

Accepted January 15, 2018

Published April 27, 2018

Keywords:

diachrony

history of language

historical lexicology

historical semantics

literary variant

\begin{abstract}
This paper stems from two different perspectives - that of the Latinists, and that of the Romanists - upon the concept of 'Vulgar Latin', perspectives that have given rise to a friendly debate between Pierre Flobert and Eugeniu Coșeriu. We try to highlight a number of lexical elements that are common to Classical and Vulgar Latin. Our approach leans upon the idea (found also with Maria Iliescu) that the diachronic vision upon language must take into consideration the sum of the histories of the words that belong to that language. Observing several lexical items excerpted from texts belonging to various epochs of the Latin culture (Archaic, Classical, Late), to various authors (Cicero, Vergilius, etc.), and to authors whose works contain elements of spoken language (Plautus, Petronius, etc.), from works of a high level language (epics, discourse, dissertation), and from texts with strong marks of orality (comedies, letters, sermons), we were able to see the semantic evolution of several Latin words preserved in the Romance languages. Our conclusion endorses the notion of a "common language", which explains the parallel existence of words like casa, pauimentum, caballus, formosus, uetulus, auricula, gula, bucca, manducare, incendere, draco both in the Classical and Vulgar Latin, without notable differences.
\end{abstract}

\section{Introduction}

The concept of 'Vulgar Latin' or 'a people's Latin', present at the core of Romance linguistics, has risen contradictory discussions even before the establishment of linguistics as science, in the $19^{\text {th }}$ century. We do not intend to enter these disputes, in which many notorious linguists have expressed opinions that have consequently been observed and continued by clearly defined linguistic schools.

However, our article stems from two different perspectives upon this concept: one held by Latinists, such as Pierre Flobert, the other, by Romanists, such as Eugeniu Coșeriu and Maria Iliescu.

Our approach concerns the lexical aspect of the concept of 'Vulgar Latin'. It will enable us to trace the belonging of various words - by dint of their continuous attestation during Latinity, at different authorsto a lexical stock common to the concept of 'Vulgar Latin' and to that of 'Classical Latin'. We believe that this approach ought to be thoroughly considered nowadays, when the researcher avails himself of digital tools that can operate the fast identification of occurrences and assist in understanding the contexts in which any Latin word has been once used. This type of approach leans on the position held by M. Iliescu, in agreement with E. Coșeriu: "Enfin, on ne considère plus l'histoire d'une langue comme l'histoire d'un tout, d'un complexe unitaire, mais comme la somme des histoires de formes et de mots"1 (Iliescu, 2013, p. 139).

\footnotetext{
*Email address: tarabogdan@yahoo.fr.

1 "Finally, we no longer consider the history of a language as the history of a whole, of a unit complex, but as the sum of the history of the forms and of the words".
} 


\section{2. "Vulgar Latin"}

There are no unitary attempts to define the notion of 'Vulgar Latin'- a fact proven by the existence of a rich terminology suggested for the same concept.

One must underline, from the very beginning, that it is subordinated, like that of 'Christian Latin', to the concept of 'Latin language', in its wholeness, without referring to a different language - a tendency that has been produced at the beginning of linguistics: "Au XIX ${ }^{\mathrm{e}}$ s. une grande partie des linguistes croyait que le latin vulgaire était une 'autre' langue latine, parlée par le 'peuple' qui se différenciait nettement du latin des personnes cultivées, du latin des auteur"' (Iliescu, 2013, p. 138). The idea of a unique language, as a transitional idiom between Latin and languages derived from it, is unacceptable in nowadays linguistics, even from the Romanists's perspective: “Ideea unei latine «vulgare» rigid unitare, care ar constitui «baza» comună și exclusivă a tuturor limbilor romanice este un reziduu al nefericitei concepții a «limbilor primitive» (Ursprachen)" ${ }^{\ddagger}$ (Coșeriu, 1997, p. 154, nota 59).

While Grandgent (1907) perceives the Vulgar Latin as "the middle class' speech", Herman (1967) believes it is "the language spoken by strata of society that have been little or even not at all influenced by education and literature"; in the same respect, B.E. Vidos (1959, p. 201, apud Haadsma \& Nuchelmans, 1963 , p. 16), extends the concept to "the language spoken by all strata, during all periods of Latinity". There is a common element in these deffinitions, namely the idea of a spoken language, therefore dynamic, subject primarily to use, and seldom to the rules of the grammatical system, thus in a permanent opposition to the written, cultivated variant of Latin.

However, the line of demarcation between the written and the spoken Latin is not an absolute one, because the two variants of the same language last throughout Latinity. Since it is subsequent to and, from then on, simultaneous with the spoken Latin, the written Latin-which, in the course of time, gains a literary aspect - was established upon the existing lexicon and upon grammatical and communicational structures that became common to spoken and written language. The fact that they underwent a refining in writing, and an evolution in speaking did not produce a decisive discontinuance; on the contrary: "le latin écrit a toujours suivi-parfois d'assez loin, évidemment-les transformations de la langue usuelle. Inversement, le style écrit, prestigieux, a marqué la langue parlée, dont le développement n’a pas été isolé et linéaire"3 (Flobert, 2014, p. 434).

Therefore, from the Latinist perspective, the "Vulgar" language draws near to the "free language of conversation", the "everybody's Latin", the "untrimmed Latin" ("sans art"), the "everyday language", or, better said, sermo cottidianus, which does not stand for a special kind of Latin, but for the "normal use" (see Flobert, 2014, p. 428).

All these notions were already present in the Latin antiquity, with various writers whose perspective "was always stylistical", points out Flobert (2014, p. 429). The same author, citing Plautus, Cicero, Varro and Quintilianus, shows that, in fact, rusticus is "the most socially and grammatically charged adjective" (Flobert, 2014, p. 429) to name an inferior level of Latin, characterised by "rural-like pronunciations" and "country-like words" ${ }^{4}$. Only with the Late Latin, beginning with the $4^{\text {th }}$ century p.C., with the Christian writers, one can see one's tendency to adopt this Latin of the uneducated-a sign that the differences have become notable. Pierre Flobert emphasizes the opposition between cottidianus, which is related to style,

\footnotetext{
2"In the $19^{\text {th }}$ century, many linguists believed that the Vulgar Latin was a 'different' Latin, spoken by the 'people', which differed clearly from the Latin of the educated people, from the authors' Latin”.

‡ “The idea of a rigidly unitary 'Vulgar Latin', that would be the common and exclusive 'fundament' of all Romance languages, is a residuum of the baneful notion of 'primitive languages' (Ursprachen)".

3“[...] the written Latin has always observed-sometimes, distantly, of course-the transformations of the everyday language. Conversely, the written style, prestigious, has influenced the spoken language, whose development has never been isolated and linear".

4 "Les urbani dénoncent à l'envi les prononciations rurales souvent admises dans l'usage (olus, foresis, coda) et les termes qui sentent la compagne (caballus, scrofa)" [Urbani blame in eager rivalry rural pronunciations that are often accepted in use (olus, foresis, coda) and country-like words (caballus, scrofa)] (Flobert, 2014, p. 429).
} 
but is nevertheless correct, and rusticus - like the periphrases with vulgo-, which eventually characterizes, beginning with the $6^{\text {th }}$ century, the incorrect language, different from the Latin of the school (see Flobert, 2014, p. 429-430). It follows that, at least up to the $6^{\text {th }}$ century-when, from the Romanistic perspective, the isoglosses common to the Classical and Vulgar Latin lessen, while new subsystems develop ${ }^{5}$ - the socalled 'Vulgar Latin' and 'Classical Latin' count more common elements than differentiating ones. But this extremely vast period (of approximately seven centuries) covers not only the conquest of new Roman provinces, but the process of their Romanization as well. Under these circumstances, the notion of 'Vulgar Latin', as language spoken ${ }^{6}$ along the entire period of Latinity, identifies with the Latin language itself, a language with natural yet irregular, diachronic and diaphasic variations, among which some are reflected in the written language, and some-in fact, the greater part of the lexicon-are present in the literary language as well.

From the other perspective, the Romanistic one ${ }^{7}$, the Vulgar Latin is the necessary binder, although not sufficient, between the attested Latin and its forms that have been preserved by the Romanic languages. It is known that Latin has been spoken until the $6^{\text {th }}$ century; and after the $8^{\text {th }}$ century, Romance. There are at least two centuries of transformations whose causes cannot be explained through linguistic evolution only, but also through historical, social, cultural evolution. There is no connection between these transformations and the epoch when the Romanization occurred, and probably there is no connection between them and the people who brought the language to provinces; these transformations, on the other hand, are connected with evolutions that occurred just on the line between Late Latin (when Latin was still a spoken language) and Medieval Latin (when Latin has become mostly the language of written communication), or, perhaps, with evolutions of a Romanic date (the Carolingian reform).

The reality suggested by Diez himself, of a people's Latin (Volkslatein) that evolves into Romanic languages, is strongly criticized by the Latinist, who goes as far as to consider it an unfounded notion: "C'est ainsi que le latin parlé, variante stylistique du latin, hypostasié en une langue qui « n’a jamais existé que dans les cerveaux de quelques savants », s’est imposé chez les romanistes sous le nom impropre de latin « vulgaire ». C'est évidemment plus confortable que de lire les travaux des latinistes..." (Flobert, 2014, p. 436). Against this very trenchant verdict comes E. Coșeriu's answer, in his article Le latin vulgaire des romanistes, written during the author's last weeks of life and published posthumously by Benjamín García-Hernández. Although he does not endorse his French friend's opinion, for he defends the existence of the concept of 'Vulgar Latin', there are not many points of disagreements between them. About the meaning of the term Vulgar, E. Coșeriu states that it draws near the meaning of cottidianus, as P. Flobert sees it: "Le Volgare (sans adjectif, certes, c'est déjà l'italien, mais appliqué à une autre langue, le terme signifie 'la langue courante', 'la langue couramment parlée', c'est-à-dire, il a à peu près la valeur que Flobert attribue à cottidianus" (Coșeriu, 2005, p. 21). Coșeriu's conclusion shows, indeed, the position held by the Romanists, which is different to that of the Latinists' tradition, because the diversity of languages with

5 "Les isoglosses communes des deux aspects du latin, au commencement nombreuses, se sont réduites de plus en plus, même si jusqu'au commencement du VIe s. les isoglosses communes, bien que moins nombreuses, étaient encore plus importantes que celles qui commençaient déjà à se constituer en sous-systèmes différenciés." [The isoglosses that are common to the two aspects of Latin, numerous in the beginning, have lessened more and more, though, until the beginning of the 6th century, the common isoglosses, while lesser in number, continued to be more important than those which were on the verge of establishing themselves in differentiated subsystems.] (Iliescu, 2013, p. 140).

${ }^{6}$ It is understood that there are no Vulgar Latin texts, but texts that contain Vulgar Latin elements.

7 “Au contraire, la plupart des romanistes, encore aujourd'hui, raisonnent inductivement à partir des faits romans en faisant grand usage du latin «vulgaire » protéiforme et complaisant; leur carapace théorique est trop souvent spécieuse." [On the contrary, as yet, most Romanists reason inductively, beginning from Romance facts, using 'Vulgar' Latin to the full a proteiform and condescending [concept]; their theoretical shell is much too often delusive.] (Flobert, 2014, p. 435).

8 "And thus, the spoken Latin, a stylistic variant of Latin, presented as a language that 'has never existed, but in a few scholars' brains', has become a reality with the Romanists, under the improper name of 'Vulgar' Latin. It is, of course, easier than to read the Latinists' works...."

9 "Volgare (without an adjective) is, of course, already the Italian language, but, when applied to a different language, the word means the 'usual language', the 'language in current use', it has almost the same value that Flobert applies to cottidianus". 
Latin origin-languages that represent a unit, but that are nevertheless different-implies the existence of a state in language that contains both tendencies: "Or, pour justifier cette unité et pour justifier en même temps les différences qu'on constate entre les langues romanes, [il faut admettre une forme de latin qui contenait déjà ce phénomène, c'est-à-dire, le phénomène qui allait devenir panroman]" ${ }^{10}$ (Coșeriu, 2005, p. 23) ${ }^{11}$. In fact, E. Coșeriu defends an opinion previously stated in detail, in 1954, in his El llamado "latín vulgar" y las primeras differenciaciones romances - a seminal paper in the field of Romance linguistics. Back in 1954, he argued that Vulgar Latin cannot be identified with an actual historical language, and that it is an abstraction that helps one to explain the inherited Latin element in the Romance languages. Being a vast concept, it includes elements belonging to Classical Latin, forms that are anterior to Classical Latin and that did not enter it, and more recent forms as well. More various than Classical Latin, it comprises elements that prove actual regional, social, stylistical and chronological differences.

About the terminology, we ought to point to one last disagreement between Latinists and Romanists. While the former, against all opposition, accept the syntagm 'Vulgar Latin', the other expression, 'people's Latin' is more frequent in works of Romanistic and history of the Neo-Latin languages. We owe E. Coșeriu the decisively explanatory observation concerning the relation between the name and the essence of the concept: "În general, conceptul de 'popor' (când nu e echivalent cu cel de 'colectivitate de vorbitori') este, în lingvistică, un concept ambiguu, ale cărui limite nu le cunoaște nimeni. Iar în cazul așa-zisei "latine vulgare" este vorba, în plus, de o petitio principii, căci înseamnă să prezinți ca demonstrat ceea ce trebuie să fie demonstrat. Într-adevăr, un mod lingvistic oarecare nu este "popular" pentru că face parte din "latina vulgară" (care nu e altceva decât latina care a fost continuată fără întrerupere de limbile romanice), ci, dimpotrivă "latina vulgară" este "populară" în măsura în care sînt "populare" modurile lingvistice care o compun. Însă așa ceva nu se poate admite anticipat, ci trebuie să fie dovedit pentru fiecare mod în parte." (Coșeriu, 1997, p. 154).

\section{Periodization}

The spoken aspect being its specific feature, it is very difficult to define Vulgar Latin from a chronological point of view, since it can be identified with the Latin itself, a spoken language that existed throughout Latinity. Hence the Latinist's deadlock: "quand le faire intervenir ? au tout début, sous l'Empire, au V siècle, ou encore plus tard: $\mathrm{VI}^{\mathrm{e}}$, $\mathrm{VII}^{\mathrm{e}}$, VIII ${ }^{\mathrm{e}}$, siècle ?"12 (Flobert, 2014, p. 437). The major problem for the researcher is that at the bedrock of any attempt of timing, with clear delimitations, lie the written attestations only. Thus, a chronology of the Latin language is apt to be confused with a periodization of the Latin literature's language, broadly speaking.

\footnotetext{
10 "But, in order to explain this unity, and also to explain the differences one sees occurring in the Romance languages, [one must admit the existence of a form of Latin that has contained this phenomenon, namely the phenomenon that would become pan-Romance]".

${ }^{11}$ Benjamín García-Hernández, who added this remark made by E. Coșeriu on his hospital bed fifteen days prior to his death, goes on and says the following, concerning Coșeriu's broad idea: "Pour lui, latin vulgaire et latin classique constituent deux niveaux d'un même continuum, de façon que latin vulgaire est tout le latin qui se développe et s'éloigne du latin fixé, c'està-dire, du latin littéraire qui, lui, ne se déroule pas en accord avec la langue parlée" [For him, Vulgar Latin and Classical Latin are two levels of the same continuum, so that Vulgar Latin is entirely the Latin that develops and moves away from the defined Latin, namely from the literary Latin, which does not carry on in agreement with the spoken language.] (Coșeriu, 2005, p. 25, note 12 ).

\$'Generally speaking, the concept of 'people' (when not equivalent to that of 'community of speakers') is, in linguistics, an ambiguous concept, whose limits are unknown to everybody. Moreover, in the case of the so-called 'Vulgar Latin', there is also a petitio proncipii, for it means to present as proved facts things that are yet to be proved. Indeed, a certain linguistic mood is not 'popular' because it belongs to the 'Vulgar Latin' (which is nothing but the Latin that has been continued uninterruptedly by the Romance languages), but, on the contrary, the 'Vulgar Latin' is 'popular' for the linguistic moods that form it are popular. Nevertheless, this cannot be accepted beforehand, but must be proved in what concerns each and every mood”.

12 “ $[. .$.$] you should accept its occurrence... when? at the very beginning, during the Empire, in the 5^{\text {th }}$ century, or later: in the $6^{\text {th }}$, the $7^{\text {th }}$, the $8^{\text {th }}$ ?".
} 
In his famous Introduction au latin vulgaire, Veikko Väänänen marks-observing the written sources (see Väänänen, 1981, p. 11-13) - the limits of several stages in the development of Latin, which, however, might be as well those of the history of Latins themselves, or of the Latin literature:

I. Archaic Latin: from origins to the end of the $2^{\text {nd }}$ century a.C.;

II. Pre-Classical Latin: from the end of the $2^{\text {nd }}$ century to the middle of the $1^{\text {st }}$ century a.C.;

III. Classical Latin ("The Golden Age”): from the middle of the $1^{\text {st }}$ century a.C. to Augustus' death (14 p.C.);

IV. Post-Classical Latin (“The Silver Age”): from Augustus' death to the year 200 (approx.);

V. Late Latin (also called bas latin): from around 200 to the advent of Romance languages.

We see that the last period is regarded as a unit, probably because the emergence and spread of the Latin Christian literature.

E. Coșeriu, in El llamado "latín vulgar" y las primeras differenciaciones romances (1954), suggests a periodization focused on the Late epoch - a transition toward the Romance languages -, in three historic stages. We render it here, with some observations concerning the relation between the written language of the epoch and the Classical and spoken Latin:

a. "Up to the $3^{\text {rd }}$ century p.C.: the Classical Latin and the Vulgar Latin are not too far apart. It may be said that there is one language, with two variants".

Although it coincides with the emergence and spread of Christianity, it is not yet the Latin of the Christian writings. The oldest biblical translations of Vetus latina can be dated to the $2^{\text {nd }}$ century, but these are fragmentary attempts to translate from Greek, while the first great Christian writer in Latin, Tertullianus (155-240), commenced his activity towards the end of the $2^{\text {nd }}$ century.

One ought to notice that this period coincides with the conquest of Dacia and with the first century of Roman dominion. So, the end of this long stage of Latin history comprises an essential part of the process of Romanization, especially northwards of Danube. This unitary language, with very similar variants, represents the stage of the Latin conveyed by the Roman army and by the colonists that lies at the bedrock of the process of Romanization. In addition to it there come the autochthonous elements, in a progressive diminution from one generation to the other.

b. "Starting with the $3^{\text {rd }}$ and $4^{\text {th }}$ centuries p.C.: the differences deepen and become more and more important, so that one may consider the existence of two distinct languages: the literary Latin and the spoken or current Latin".

This is the century when Christianity becomes the official religion of the Roman Empire. How can be illustrated the literary language of this period, when the texts of the most representative Christian writers appear? Through their mentality determined by a new type of spirituality, in accordance with the biblical text, which functions as a model, and in accordance with the need for understanding among all Christians, regardless any social status, these authors contribute, through their writing, to the unity of Latin. When speaking (as preachers), as well as when writing (as authors of a Christian theology), they aim to reach any type of listener or reader. Thus, the Christian Latin is less relevant when it comes to the opposition between written vs spoken and cultivated language vs people's language. It is, however, in opposition with the pre-Christian Latin, which, in fact, it follows naturally, with modifications, mainly lexical (after the limited borrowings from Greek and Hebrew) and semantic (by assigning or changing in the meaning of some words, under the pressure of the new religion).

This is the Latin of the last seven decades in the existence of Dacia as a province of the Roman Empire, and the Latin of the first generations of inhabitants who can be considered completely Romanized. As far as the Latin has spread over the territory, the inhabitants live in a linguistic and cultural Latin environment, and have access to all the resources provided by the language at that given moment. Assuming this perspective, there are no reasons to believe that important lexical selections have been carried on with regard to Latin as a complex instrument of communication in use on different levels. 
c. "Until the $6^{\text {th }}$ century: One can say about the spoken Latin that, by the $6^{\text {th }}$ century, it became one language".

The spoken language, though not fundamentally different from the written language of the epoch, characterizes different forms of communication. Being the last great Christian writer of the Late period, pope Gregorius Magnus (540-604) is known for his Dialogs-writings addressed to the masses, enjoying a great success then. The texts, very popular and accessible, are not written in a 'people's' Latin. The lexicon, when it does not express Christian realities, is common, and can be attested in various epochs of Latin.

In a territory left outside the Latin continuum, like Dacia, one can presume that the tendencies of separate evolution become more intense. Lacking the unifying theological and linguistic influence, brought by the ecclesiastical organization of the Occidental Church, this space cannot experience but centrifugal tendencies. A Christian way of living has already been established in the West after the translation of the whole Bible into Latin, and through authoritative commentaries, through series of homilies of great Latin preachers, preserved and handed down in written form, through the settling of the monastical life, through a Christian theology, and even through a Christian literature. This unitary cultural model was absent northwards of Danube, and the withdrawal of the Roman administration and the decline of the urban-like establishments-as centres of influence towards the smaller communities-were paving the way for evolutions of unclear pattern. They were mainly innovations (in form and meaning), as well as selections of terms - a process that, in time, led to the loss of a significant part of the Latin vocabulary in Romanian, and in the other Romance languages.

\section{The relation between the lexicon of Vulgar Latin and that of Classical Latin}

The most important papers and books concerning the history of the Romanian language have thoroughly studied the lexicon inherited by Romanian from Vulgar Latin, trying to explain the evolution of forms (by dint of the phonetic laws), of meanings, explaining the selection of words in accordance with historical events and social, cultural, etc., particularities of the Romanized population.

Starting from the idea that these terms used to belong to the spoken language of the common people, we believe that only an excursion through the attestations of each and every word in different epochs of Latinity would be able to show the close relation between Vulgar and Classical Latin. The remark "Il ne faut pas oublier non plus que toutes les formes et mots du latin littéraires ont une fois été des formes du latin courant, parlé [...]"13 (Iliescu, 2013, p. 142) sets down the most natural connection between the two variants of the Latin language, through vocabulary. The existence of a word simultaneously in the Classical Latin and in the so-called 'Vulgar Latin' of the Late period proves that it belongs to the common Latin, which has a spoken aspect as well as a written one; the latter being carried on mainly through the Latin of the Christian texts, as a form of the Latin of the Late period.

In order to be in the position to conclude that a certain word is not specific to Vulgar Latin, but to the common Latin, we have settled two criteria:

a. it has to be attested throughout Latinity (if it shows up during the Archaic period, and also during the Late period, one may assume its existence during all periods, because it is unlikely that the term was abandoned in speech, only to be resumed later);

b. it has to be attested in the cultivated literature of the Classical period, but also with the great ecclesiastical writers, especially in dissertations (texts of a high-level language, that have a level of orality lower than that of sermons, homilies and epistles).

We have examined the evolution of the meanings, by virtue of contexts, during the three large periods (Archaic, Classical, Late), in order to register any possible semantic innovation, that might have occurred

\footnotetext{
13 "We must not forget the fact that all forms and words of the literary Latin once used to be forms of the current, spoken Latin $[\ldots]$...
} 
sometime during the Late period or with authors whose works are known to contain vulgarisms (e.g., Plautus, Terentius, Petronius, Apuleius), in contrast with the works of the so-called Classical writers (Vergilius, Lucretius, Horatius, Ovidius etc.).

For this paper, we have arbitrarily—though not randomly—chosen 11 Latin words, whose attestations have been observed in a vast corpus of Latin literature (published by Brepols: CLTCLT-5).

\section{1. $\boldsymbol{C A S A}$ (pan-R.)}

It is one of the words that denote a piece of reality known to the common and poor people. One may ask if this fact would be a sufficient reason to believe that the word itself belongs exclusively to the spoken language, a level of language that is inferior to Classical Latin.

The term is not found at Plautus, but it shows up at Terentius (sec. II a.C.), in a proverb where casa already has the general meaning of 'house': Ita fugias ne preter casam (Phormio 768) "so run away as [not to run] beyond the house" ${ }^{14}$. What for the common people is 'house', in general, for those who belong to superior social levels is only a 'hut, cottage, poor abode'. Superior, Quintilianus shows the benefits of the human progress, without which domibus quidem casas aut vestibuspellium tegmina aut urbibus montes ac silvas mutari (Institutio oratoria 9, 4, 4) "huts should never have been relinquished for houses, dresses of skins for decent apparel, or mountains and forests for cities". The word is present at various Classical writers, who either despise or warmly accept the idea expressed by it, according to the context.

Vergilius (Bucolica 2, 28) connects humiles casas "small huts" with sordida rura "dirt of the countryside". For Lucretius (De rerum natura 6, 1254), casa is the place where the shepherd and the farmer come to die of sickness and poverty. In Elegie, Propertius uses the word five times, with a deprecating meaning, clearly indicated by the determinative: immunda casa $(2,23,9)$ "dirty hut", sine arte casa $(4,1$, 5) "a hut maladroitly (built)", putris casa $(4,9,28)$ "a hut in ruins", summota casa $(5,9,56)$ "a remote hut". For Ovidius (17 oc.) casa is the hut e ramis frondea facta (Fasti 3, 527) "made of branches, covered with leafage", but also the hut from the beginnings of Rome, when the people were poor, and, nevertheless: dum casa Martigenam capiebat parua Quirinum (Festi 1, 199) "when a small hut sufficed to lodge Quirinus, son of Mars", because: hic, ubi nunc Roma est, orbis caput, arbor et herbe / et pauce pecudes et casa rara fuit (Fasti 5, 93-94) "here, where now stands Rome, the capital of the world, there were trees, grass, / a few sheep, and a few cottages".

Cicero ( 5 oc.) recounts that he has been in casas aratorum, a stiva ipsa homines mecum colloquebantur (Pro M. Emilio Scauro oratio 25, 1) "the cottages of the farmers; men talked with him at the plough", and that to Ptolemy himself, in Egypt, cibarius in casa panis datus esset (Tusculane disputationes 5, 34, 97) "some coarse bread was given him in a hut", and nothing ever seemed to him of sweeter taste than that bread.

Titus Livius tells who this type of abode was specific to; the author asks himself: non in casis ritu pastorum agrestiumque habitare est satius? (Ab Urbe condita 5, 53,7) "is it not better to dwell in cottages, like shepherds and rustics?".

In the $2^{\text {nd }}$ century, one can detect a change with Apuleius (Metamorphoses 3, 29), who talks about casas amplas "spacious abodes", in contrast with uillulas "small houses".

With a single occurrence in the biblical text (Liber sapientic $\left.{ }^{15} 11,2\right)$ : in locis secretis fixerunt casas "şi şi-au înfipt corturile în locuri nemaiumblate" (Septuaginta IV/2, p. 203), the word does not seem to be specific to the Christian literature. Blaise (1993, s.v. casa) finds it at various later authors, having the meaning of 'farm, property, estate', but also of 'brothel'; in each case, the occurrences are few.

Tertullianus (Aduersus Iudeos 3, 23) and Cyprianus (Ad Qurinum 1, 6, 3), quoting Isaias, 1, 8, use sicut casa in uinea "like a hut in a vineyard", where Hieronymus would translate, in Vulgata, cu sicut umbraculum in vinea "like a tent of leaves in a vineyard". At Ambrosius, we read pastorales casas "cottages of shepherds"

\footnotetext{
${ }^{14} \mathrm{Cf}$. "Si tu es en fuite, ne passe pas devant la maison" (trans. Marouzeau, 1990, CuF).

${ }^{15}$ Book of the Wisdom of Solomon.
} 
textitExpositio euangelii secundum Lucam 7, 465; Epistule 10,73, 30), and at Augustinus: casas in uicis "houses in villages" (Enarrationes in Psalmos 80, 2; 80, 17).

Finally, the word receives a much more important meaning with the Christian exegesis: tabernaculum autem illud, id est casa ubi Abraham pro tempore manebat, figura erat ciuitatis Ierusalem in qua <pro> tempore lex et prophete, ipse quoque dominus et apostoli habitauerunt [...] (Gregorius Illiberitanus, Tractatus Origenis de libris Sanctarum Scriptarum 2, 63) "That tent, which is the hut where Avram remained, according to circumstances, was the image of the citadel of Jerusalem, in which, according to circumstances, lived the law and the prophets, the Lord himself, and the Apostles".

In conclusion, we see that the term casa denotes a reality common to a large social class living at the bottom of the Roman society. The word remains in use throughout all epochs, and does not suffer a significant semantic change. Its preservation in the Romance languages must be linked to the preservation of a rural kind of life. We believe that the decline of the urban life, across the Empire (cf. Ivănescu, 2000, p. 172), did not spontaneously lead to the generalization of casa, but, more likely, to the gradual loss of domus.

\subsection{PAVIMENTUM ${ }^{16}$}

The fundamental meaning of pavimentum, $-i$ is 'beaten ground', and is a deverbal from pavio, -ire, -ivi, -itum 'to beat (the ground), to level'; the meaning of the word evolved, through specialization, to 'slab floor or mosaic, pavement'. With its initial meaning, pavimentum is the beaten ground inside or around the house (see Rom. bătătură). In the case of a rich household, pavimentum is made of slabs, while in poor households it is only trodden ground. Cato, De agricultura 18, 7, Vitruvius, De architectura 7, 1, 1-5, and Pliny the Elder, Naturalis historia 36, 185 give an accurate account of the paving techniques across time; Pliny even states the connection between the origin of the word and an old Italian custom, met in poor households ${ }^{17}$.

With the meaning 'ground' (Blaise, 1993, s.v. pauimentum: "le sol"), 'dirt' ${ }^{18}$, the word is used in Vulgata, Num, 5, 17: adsumetque aquam sanctam in vase fictili et pauxillum terre de pavimento tabernaculi mittet in eam "apoi va lua preotul apă vie, curată, într-un vas de lut, va lua țărână din pământul de dinaintea cortului mărturiei” (Anania, 2001, p. 162); "și să ia preotul apă curată, vie, într-un vas de lut și țărână din bătătura cortului mărturiei” (Septuaginta I, p. 442) [“And the priest shall take holy water in an earthen vessel; and of the dust that is in the floor of the tabernacle the priest shall take", KJV], and $P$ s, 118, 25: adhesit pavimento anima mea "Sufletul mi s'a lipit de pământ" (Anania, 2001, p. 755); "Lipitus-a de țărână sufletul meu" (Septuaginta IV, p. 292) [cf. Ps, 119 (118), 25: "Me voici collé à la poussière", тов; cf. "My soul cleaveth unto the dust", KJV]. Ambrosius explains this passage in a conclusive manner: per pauimentum terram intellegimus, per terram materialia (Expositio psalmi 118, 4, 2) "we understand pauimentum as ground, and ground, as material things".

In conclusion, the word appeared in writing during the $2^{\text {nd }}$ century a.C., with its basic meaning at Cato (De agri cultura), and with particular meanings, depending on the context, at the majority of the pre-Christian writers (Horatius, Cæsar, Cicero, Seneca, etc.). The existing meanings correspond to various extralinguistic realities. In Romanian, the generalized meaning 'ground' is not necessarily the result of a later evolution, since one can find it at pre-Christian writers, as well as in the late, Christian Latin.

\footnotetext{
16 “Astfel pavimentum 'teren pavat, pardosit', 'pavaj', 'mozaic', a ajuns să însemneze 'pămînt”' [Thus, pavimentum 'paved ground', 'pavement', 'mosaic' began to mean 'ground'”] (Ivănescu 2000, p. 174). It represents a semantic evolution "numai în latina populară din Dacia, și anume din cauza rusticizării vieții” [specific to the popular Latin of Dacia, due to the ruralization of life] (Ivănescu, 2000, p. 174).

${ }^{17}$ Pavimenta credo primum facta que nunc vocamus barbarica atque subtegulanea, in Italia festucis pavita "Je crois que les premiers pavements effectués furent ceux que nous appelons à présent barbares et pavements sous couvert. Ces sols battus furent en Italie faits à l'aide de hies, c'est ce qui du moins peut s'entendre du nom même”. (trans. Bloch, 1981, CUF).

${ }^{18}$ Cf. pavimentum stratum lapide "ground covered with stone" (Ezek, 40, 17).
} 


\subsection{CABALLUS (pan-R.)}

The word does not have many occurrences in Latin, but it appears in every epoch. During the $2^{\text {nd }}$ century a.C., it is used by Lucilius, Saturarum fragmenta (in aliis scriptis seruata), v. 163, in a depreciative context: succusatoris, tetri tardique caballi, talking about the "horse that jolts you, ugly and slow". It is the horse of the field, the gelded horse, that draws and carries burdens and loads. In this respect, it is the opposite of equus, $-i$, the horse for riding and equitation, and cavalry. There is a functional opposition between the two terms, that lasts through all epochs. And yet, caballus, like equus, may receive the broad meaning of 'horse', in a more or less explicit context: Quid, uos, inquit? iumentum me putatis esse aut lapidariam nauem? Hominis operas locaui, non caballi. (Petronius 117) "What, tell me, you take me for a beast of burden, or for a ship good to carry stones? I intend to do the chores of a man, not of a horse"; O quantum erat seculi decus, imperatorem triumphalem, censorium, quod super omnia hac est, Catonem uno caballo esse contentum et ne toto quidem. Partem menim sarcine ab utroque latere dependentes occupabant. (Seneca, Epistule morales ad Lucilium 87, 10) "O what a glory to the times in which he lived, for a triumphant emperor, a former censor, and what is most noteworthy of all, a Cato, to be content with a horse, and with less than a whole one at that. For part of it was pre-empted by the baggage that hung down on either flank".

With Horatius (he uses the term 5 times, more than any other writer), caballus may be the country horse of a rich landlord: [...] non ego me claro natum patre, non ego circum / me Satureiano uectari rura caballo, [...] (Sature 1, 6, 56) "[...] I do not say that I was sprung from noble sire, nor that I rode around some country-seat on horse of purest breed".

During the Late period, caballus occurs in great texts of the Christian literature: dicebat [...] caballum se scilicet factum annonam inter alia iumenta baiulasse militibus [...] (Augustinus, De ciuitate Dei 18, 18, 52) "it said [...] that it had been changed into a horse and that it had carried food for soldiers, alongside other beasts of burden". Employed by solders to carry baggage's and food, caballus is seen as a depreciative word, in opposition to equus; nevertheless, the context it the one that gives the word that particular nuance of meaning: [...] et non intellegimus prophetarum uoces: fugient mille unopersequente nec amputamus causas morbi, ut morbus pariter auferatur, statimque cernimus sagittas pilis, tiaras galeis, caballos equis cedere? (Hieronymus, Epistuale 60, 17) “[...] and we do not understand the prophet's words: 'one thousand shall flee at the rebuke of one', and we do not cut away the causes of the disease, as we must do to remove the disease itself; else we should soon see the enemies' arrows give way to our javelins, their caps to our helmets, their palfreys ${ }^{19}$ to our horses ${ }^{20}[\ldots]$ ".

We may conclude that caballus, being present during all periods, at many of the cultured authors, does not belong to Vulgar Latin, but designates an extralinguistic reality common mainly to the rural world, but also to the military domain. Similar to all the beasts of burden (the ox, the donkey), it may receive depreciative connotations, but it is still an indispensable being.

\subsection{FORMOSUS (Rom. It., Prov., Sp., Port.)}

The first attestation of the word is with Plautus, where it is employed to describe an animal: Mercari uisus mihi sum formosam capram (Mercator 229) "I was told that I had bought a beautiful goat ${ }^{21}$. In the Archaic period, there are, as well: virginem formosam (Titinius, Comodiarum fragmenta 18) "beautiful virgin", and formosus homo (Lucilius, Saturarum fragmenta 418) "beautiful man".

During the Classical period, Propertius uses the word many a time in Elegie, in a variety of situations, in a large spectrum that covers the abstract, as well as the concrete: humus formosa $(1,2,9)$ "beautiful land", formosi temporis atas $(1,4,7)$ "the times of beautiful days", formosa Doride $(1,17,25)$ "beautiful Doris ${ }^{22}$ ",

\footnotetext{
${ }^{19}$ In fact, "horses of burden".

20 "Horses of war, chargers".

21 "Une chèvre de toute beauté." (trans. Ernout, 1992, CUF).

${ }^{22}$ Okeanos' daughter, the Nereids' mother.
} 
formosos pedes $(1,18,10)$ "beautiful feet", formose heroine $(1,19,13)$ "beautiful heroines", etc. ${ }^{23}$. As a noun or an adjective, Ovidius uses the word in almost all his writings: Amores (21 occ.), Ars amatoria (9 occ.), Epistule ex Ponto (1 occ.), Fasti (9 occ.), Heroides (13 occ.), Metamorphoses (23 occ.), Remedia amoris ( 4 occ.), Tristia ( 1 occ.). In the majority of cases, the author employs the feminine adjective form favourably, in: formosa puella "beautiful young lady"; but, on the whole, the usage of the word varies: Non formosus erat, sed erat facundus, Ulixes (Ars amatoria 2, 123) "Ulysses wasn't beautiful, but a skillful talker"; formosissimus annus (Ars amatoria 2, 315) "the year is very beautiful"; formosa manu (Ex Ponto 1, 10, 12) "with beautiful hand"; formosa Venus formoso tempore digna est (Fasti 4, 129) "beautiful Venus deserves a beautiful season", etc. Horatius (3 occ.) employs the construction mulier formosa (De arte poetica 4) "beautiful woman". The term is used by Cicero (17 occ.), who, in one of his letters, confesses: nibil est enim, mibi crede, virtute formosius, nibil pulchrius, nibil amabilius (Cicero, Epistule ad familiares $9,14,4)$ "Believe me, nothing is more beautiful, more praiseworthy, more loveworthy than the virtue".

Although absent from the biblical texts, formosus is present at Augustinus ( 42 occ., in dissertations and sermons), and at Hieronymus (33 occ.). With a figurative meaning, which excludes any interpretation concerning the beauty of shapes, we find the term at Augustinus: [...] illa pre cunctis formosa et luminosa ueritas tua. (Confessionum libri tredecim 2, 6, 23) “[...] Your truthfulness ${ }^{24}$, more beautiful and brighter than all"; anime [...] formose (De ordine 1, 8,71) "of the beautiful [...] soul”, etc.

Thinking, probably, that the term does not develop a really special meaning in the Christian literature, Albert Blaise does not create a separate article for formosus in his Dictionnaire latin-français des auteurs chrétiens - which could mean that formosus preserved during the Late Latin the meanings that it used to be employed with during Archaic Latin, and that were active during Classical Latin as well.

\subsection{VETULUS (pan-R.)}

As the diminutive form of the adjective vetus, - eris (the antonym of nouus), the word bears the meaning of 'old', in the Classical Latin, for people, and for animals and plants. It is often employed as a noun: uetulus, $-i$ "an old (man)" and uetula, $-\alpha$ "an old (woman)". It is not a frequent word; however, it is attested in all epochs.

At Plaut (10 occ.), the opposition senex (about the master) vs uetula (about the sheep) has not but a stylistic value in the fragment: Mi senex, tam uetulam? (Mercator 525) "Așa bătrînă, moșule?".

At Lucretius there is: tristis uetula uitis sator (De rerum natura 2,1168) "the sad grower of an old vineyard"; and Horatius (Carmina 3, 15, 16; 4, 13, 25) describes as uetule "old" two well-known characters of the epoch, whom he ridicules. Cicero $(5$ occ.) uses the term, in various registers, for gladiatore uetulo (Pro P. Quinctio oratio 29, 16) “old gladiator (in his trade's secrets)", for uetuli equi (Lelius de amicitia $67,6)$ "old horses", different from the teneri "young", for a woman uetula sane et multarum nuptiarum (Epistule ad Atticum 13, 28, 4) "too old and many a time married", but also as a friendly name, regardless of age: mi uetule (Epistule ad familiares 7, 16) "Old man!".

It is only natural to find that Varro, in Res rustice, links the adjective uetulus, -a "old" to catuli (2, 9, $3)$ “dogs", boues $(2,5,6)$ “oxen”, columbe $(3,7,8)$ "doves", galline $(3,9,9)$ "hens".

In order to ridicule the tasteless master, who does not know to select his servants, Petronius uses the construction puer uetulus (Satyrica 28, 4, 11) “old boy". The word is often employed in Martialis' epigrams (19 occ.), and in Iuvenalis' satires (7 occ.).

In the Christian literature, vetulus seldom appears, and with a small number of authors, e.g. Augustinus uses it once (Contra Faustum 14, 15Hieronymus uses it more often (10 occ.), concerning uxor (Liber questionum hebraicarum in Genesim 39, 4) "wife" ${ }^{25}$, uirgo (Commentarii in Isaiam 3, 7, 14) "virgin",

\footnotetext{
${ }^{23}$ Observe the seeming opposition formosa vs. pulchra (Propertius, Elegie 2, 28, 49): sunt apud infernos tot milia formosarum: / pulchra sit in superis, si licet, una locis! "Il y a dans les lieux infernaux tant de miliers de belles: qu'il y ait une beauté, s'il est permis, dans ceux d'en haut!" (trans. Viarre, 2005, CUF).

24 "The truth".

${ }^{25}$ It sends to Genesis, chapter 18.
} 
mulieres (Commentarii in IV Epistulas paulinas, Ad Titum 613) “women”, etc. The same author gives a clear explanation about the functional value of the word: caueant ergo, ut diximus, tam iunenes quam senes, tam adolescentula quam uetula (Commentarii in IV Epistulas paulinas, Ad Titum 614) "they ought to beware, as I have said, the young women, the old women too, the young girls, the oldish".

In Vulgata, the word occurs two times only: dominus meus vetulus est (Gen, 18, 12) "my master is old", and: ante eritis vetula $($ Ruth, 1, 13) "you would be old before".

Without being frequent, the word is nevertheless present throughout the epochs of the Latin literature, and one cannot detect any evolution or change in its meaning. It is noteworthy that the adjective does never determine nouns of inanimate objects.

\subsection{AURICULA (Rom., It., Retr., Fr., Sp., Port.)}

Although, by form, it is the diminutive of auris, auricula has a specialized meaning: 'the external part of the ear, the flap' (Gaffiot, 2000, s.v. auricula) ${ }^{26}$; so, the visible part of the ear, most frequently associated with the whole organ. With this meaning, it is used by Plautus, during the Archaic period: Sine te exorem, sine prehendam auriculis, sine dem sauium. (Ponulus 374) "Do let me prevail upon you; do let me take you by the ears; do let me give you a kiss.", and by Cicero, during the Classical period: [...] auriculam fortasse mordicus abstulisset [...] (Epistule ad Quintum fratrem 3, 4, 2, 3) "[...] he would, perhaps, have bitten off my ear [...]”. Neither the word itself, nor the part of the body it designates do not imply the idea of vulgarity. On the contrary, auricula is the synonym of auris at Plinius Maior, who tells that: est in aure ima memoria locus, quem tangentes antestamur; (Naturalis historia 11,251) "the seat of the memory lies in the lower part of the ear, which we touch when we summon a witness to depose upon memory to an arrest". Horatius too refers to the same custom: [...] oppono auriculam. (Sature 1, 9, 75) "[...] I offer my ear" (to indicate the consent to be someone's witness in court).

Even from a medical point of view, at Celsus, auricula is synonymous with auris; he mentions, among other summer illnesses, auricularum dolores (De medicina 2, 1) "the pains of the ears".

Other poets who, during the $1^{\text {st }}$ century a.C., have used the word are Lucretius, De rerum natura 4 , 592; Propertius, Elegie 1, 16, 27; Catullus, Carmina 67, 41; etc.

In Christianity, auricula maintains the ancient meaning 'ear', and is rather frequent in various dissertations and sermons, due mainly to a couple of famous biblical fragments (of the 19 occ.): sumes de sanguine ipsius et pones super extremum dextre auricula Aaron [...] (Exodus, 29, 20) "Să iei din sîngele lui şi să pui pe lobul urechii drepte a lui Aaron [...]" (God commands to Moses), and: et ecce unus ex his qui erant cum Iesu extendens manum exemit gladium suum et percutiens servum principis sacerdotum amputavit auriculam eius (Euang. sec. Mattheum, 26, 51) "și iată, unul dintre cei ce erau cu Iisus, întinzînd mîna a tras sabia și, lovind pe sluga arhiereului, i-a tăiat urechea”.

Among the Christian writers, we mention: Tertullianus, De pudicitia 13, 61; Lactantius, De mortibus persecutorum 36, 7, 28; Arnobius, Aduersus nationes 1, 52, 1, etc.; Ambrosius, Expositio enangelii secundum Lucam 7, 852, etc.; Paulinus Nolanus, Epistuale 49, 14, 24; Augustinus, In Iohannis euangelium tractatus 102, 4, 26, etc.; Hieronymus, Aduersus Iouinianum 2, 25, 5, etc.

The frequency of the word in Classical and Late literature, with an unambiguous and generalized meaning, allows us to ascertain that it belongs to the common lexical stock of Latin.

\subsection{GULA (pan-R.)}

At Plautus, in the same comedy, the word means 'mouth': follem obstringit ob gulam [...] ne quid anime forte amittat dormiens (Aulularia 302) "he ties a bag over his mouth [...] lest he should lose his breath whilst he's asleep", and 'throat': Ibo intro atque illi socienno tuo iam interstringam gulam (Aulularia 659) "I'll go in and straightaway I'll drag your comrade by his throat".

Ovidius employs the metaphor flamma guld (Metamorphoses 8, 845-846) to express "the lust of greediness", and Horatius constructs a hyperbolic comparison: Harpyiis gula digna rapacibus (Sature 2, 2,

26 "Oreille [considérée dans sa partie externe]". 
39) “a mouth worthy of the greedy harpies”. Stayed famous Cicero's depreciative exclamation: O gulam insulsam! Pudet me patris. (Epistule ad Atticum 13, 31, 4) "What a tasteless man ${ }^{27}$ ! I'm ashamed for his father!".

The word is usual, attested with some of the best-known writers of Antiquity: Varro, Sallustius, Seneca, Petronius, Martialis, Iuuenalis, Tacitus, Plinius Maior, Aulus Gellius, Apuleius. The majority of the occurrences is to be found with Christian authors: Tertullianus ${ }^{28}$, Lactantius, Ambrosius, Eusebius Cæasariensis, Paulinus Nolanus, Augustinus (in sermons, dissertations, even in Confessionum libri tredecim 1, 19, 10, where the author recalls how he used to steal out of greed: gula imperitante ${ }^{29}$, Iohannes Cassianus, Hieronymus, etc.; however, the word is absent from the Bible.

Although mostly used in negative, deprecatory contexts, gula does not belong to the language of the non-educated. It may be found with the slave, but also with the master, and often refers to a feature of character: greediness.

\subsection{BUCCA (pan-R.)}

Plautus employs the term in many occasions, with a clear meaning: Age, iam infla buccas [...] (Stichus 767) "Come now, inflate your cheeks [...]".

At Cicero, there is the actual meaning of 'cheeks': Gallum [...] eiecta lingua, fluentibus buccis (De oratore $2,266,12$ ) "a Gaul with the tongue protruding and the cheeks baggy", and there is the figurative meaning 'mouth', in the formula repeated at the end of the letters: si rem nullam habebis, quod in buccam

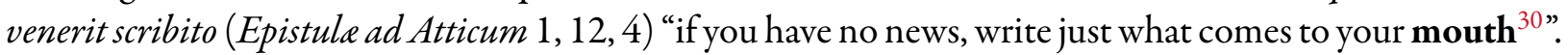

Petronius uses the word three times, with different meanings: 'gulp, mouthful': non mehercules hodie buccam panis invenire potui (Satyrica 44, 2, 24) "I couldn't even get a mouthful of bread today, by Hercules"; 'cheeks': ut mucronem ad buccam probaremus (Satyrica 70, 3, 16) "even giving us the chance to try their edges [of knives] upon our cheeks"; and, figuratively, 'mouth' in: dure bucca fuit, linguosus [...] (Satyrica $43,3,25)$ "he was foul ${ }^{31}$-mouthed, had a ready tongue $[\ldots]$ ".

During the same $1^{\text {st }}$ century p.C., in a text of scientific nature, Plinius Maior employs the word as 'mouth': quibus gene non sint, de malis, de naribus, buccis, labris, mento, maxillis de dentibus qua genera eorum (Naturalis historia 1, 1, 45) "[animals] that have no cheeks, about jaws, about nostrils, [about] mouth, lips, chin, maxillæ, about teeth [...]”, and as 'pleat, cheek dimple', very clearly stated as such: Infra eas hilaritatem risumque indicantes bucce [...] (Naturalis historia 11, 158, 10) "beneath them are the cheeks that show joy and laughter".

We find the word with Cato, too, in Origines 7, 5, 8 (cited by Aulus Gellius, Noctes attice 2, 22, 29, and by Apuleius, De mundo 14, 3), Suetonius, De grammaticis et rhetoribus 29, 1, 15.

During the Christian period, it appears frequently at Augustinus, in Confessionum libri tredecim 4, 16, 1, when the author evokes his teacher, the rhetor form Cartagena, who used to cite from Aristotle, "with cheeks swollen with pride" (buccis typho crepantibus), and in Epistula 3, 5 25, where he uses an expression one can find at Cicero as well (quod in buccam uenerit). The same construction is employed by Hieronymus: dictare quodcumque in buccam uenerit (Commentarii in prophetas minores, In Abdiam 776) "to say whatever comes to their mouths". The same work contains the word as 'cheeks': rubentes buccas (In Micheam 1,313) "red cheeks".

In Vulgata, only the diminutive buccella is attested, most often in buccella panis "a small gulp of bread", alluding to the Eucharistic bread.

Being attested through all epochs and with cultured authors, we may conclude that the term is current, not specific to Vulgar Latin.

\footnotetext{
${ }^{27}$ Lit.: "What an unsalted mouth!".

${ }^{28}$ Fig.: temporum gula, Res. 4 "la gueule du temps (qui engloutit les vivants)" (Blaise, 1993, s.v. gula).

${ }^{29}$ Lit.: "Being commanded by his mouth".

30 "what comes uppermost".

31 "wicked".
} 


\subsection{MANDUCARE}

The noun manducus, $-i$ "Glutton" 32 , from which derived the verb manducare 'to chew; to eat', appears firstly at Plautus, Rudens 535, and the participle manducatum is used by Varro to say that little pigeons must be fed with manducato candido pane (Res rustice $3,7,9$ ) "chewed ${ }^{33}$ white bread". Celsus (De medicina 4, 3, 13; 4, 4, 22; and 4, 11,25) employs the verb with the meaning 'to chew', about mustard seeds (sinapi) and a plant called (Rom.) portulacă. In these contexts, it is not a vulgar word; on the contrary, appearing in a specialized text, whose author $\left(1^{\text {st }}\right.$ century a.C. $-1^{\text {st }}$ century p.C. $)$ is recognized as a doctor and an encyclopædist, it is employed with a precise meaning.

The general meaning 'to eat' is present, during the Late period, with Petronius. The two contexts represent conversations held by common people, whose way of speaking coincides with one may call 'Vulgar Latin': inueniemus quod manducemus pullum, oua (Satyrica 46, 2, 10) "we shall find something to eat, a chicken, some eggs"; boues, quorum beneficio panem manducamus (Satyrica 56, 4, 27) "the oxen, thanks to which we eat bread".

The surprise comes from Suetonius $\left(1^{\text {st }}-2^{\text {nd }}\right.$ century p.C. $)$ who, writing about the culinary habits of Octavianus Augustus, uses the verb manducare when citing from a letter of the emperor himself: et rursus: ne Iudaus quidem, mi Tiberi, tam diligenter sabbatis ieiunium seruat quam ego hodie seruaui, qui in balineo demum post horam primam noctis duas buccas manducaui prius quam ungui inciperem. (De uita Casarum, Diuus Augustus 76, 2, 8) "Once more: 'My dear Tiberius, not even a Jew fasts so scrupulously on his sabbaths as I have today; for it was not until after the first hour of the night that $\mathbf{I}$ ate two mouthfuls ${ }^{34}$ in the bath before I began to be anointed'". Although the author tells us about the emperor that "[h]e was a light eater and as a rule ate of plain food" (cibi minimi erat atque uulgaris fere), we cannot state the same thing about his manner of speaking and using the language. Manducare belongs to informal language, that characterizes the epistolary style of many great writers.

Nevertheless, the verb becomes truly current during the epoch of Christian literature (with Tertullianus, Augustinus, Hieronymus, etc.), mainly due to its use in biblical texts (about 180 occ.), meaning 'to eat', in opposition with bibere 'to drink': venit Filius hominis manducans et bibens et dicunt ecce homo vorax et potator vini [...] (Vulg, Mat, 11, 19) "A venit Fiul Omului mîncînd și bînd, și spun: Iată om mîncăcios și băutor de vin [...]” (Anania, 2001, p. 1473) [“The Son of man came eating and drinking, and they say, Behold a man gluttonous, and a winebibber”, KJv]). However, the initial meaning 'to chew, to break with the teeth' is still strong in some of the contexts: in illo tempore abiit Iesus sabbato per sata discipuli autem eius esurientes coeperunt vellere spicas et manducare (Vulg, Mat, 12, 1) "În vremea aceea mergea Iisus printre holde într'o zi de sîmbătă, iar ucenicii Săi au flămînzit și au început să smulgă spice și să mănînce” (Anania, 2001, p. 1473) [“At that time Jesus went on the sabbath day through the corn; and his disciples were an hungred, and began to pluck the ears of corn, and to eat.", KJv]. The chewing of grains may be related to the chewing of the mustard seeds, from Celsus (see supra).

We may thus conclude that the Classical meaning 'to chew', and the post-Classical one 'to eat' are both attested during the Late period, of the Christian literature. It is highly possible that its frequent employment in biblical texts played an important role in its preservation and generalization.

\subsection{INCENDERE (Rom., It., Retr., Prov., Cat., Sp., Port.)}

The derived form from candere is almost perfectly synonymous with accendere (cf. Ivănescu, 2000, p. 173), sharing the meanings 'to start a fire, to inflame, to burn; (fig.) to light, to inspire/fill with enthusiasm, to incite' (Gaffiot, 2000, s.v. incendo and accendo: 'allumer, embraser, (fig.) enflammer'). Even considering their figurative meanings, the two words are interchangeable at a fine writer such as Cicero: luna incensa

\footnotetext{
${ }^{32}$ Ancient character, depicted as a creature with an enormous mouth.

33 "Crumbled".

34 "I ate in a hurry".
} 
radiis solis ${ }^{35}$ (De natura deorum 1,87 ), and: luna radiis solis accensa $a^{36}$ (De republica 6, 17) for "the moon lighted by the rays of the sun".

The frequency of the verb is endorsed by the popularity of the noun denoting the outcome of the action: incendium vs. accendium (a rare term).

Incendere is current with the authors of the Archaic period: Ennius, Plautus ( 5 occ.), Terentius ( 4 occ.), Cato ( 3 occ.), and also with those of the Classical epoch. In Eneida, Vergilius employs it metaphorically, in combination with words like: reginam $(1,659)$ "the queen"; animum $(4,197$ and 6, 889) "the soul"; auro squamam $(5,88)$ "with gold, the scales"; vires $(5,455)$ "the strengths"; luctus $(9,500)$ "the sorrow"; calum $(10,895)$ "the sky"; clamoribus urbem $(11,147)$ "with cry, the town", and only once with its proper meaning: aras $(3,278)$ "the altars". In Bucolice, however, with: laurus $(8,82)$ "the laurel", and in Georgice, with: agros $(1,84)$ "the fields"; vepres $(1,268)$ "the thorns"; galbaneos odores $(4,264)$ "the scents of resins", it bears the concrete meaning only. The word is found with poets: Propertius, Ovidius ( 3 occ.), but mostly with historians: Titus Livius (20 occ.), Sallustius (10 occ.), Cæsar $(24$ occ.); at Cicero (more than 60 occ.), it is present in discourses and dissertations; Seneca (16 occ.), Tacitus (10 occ.), Pliniu Maior (6 occ.), Suetonius ( 3 occ.), etc. use the term as well.

Over 40 occurrences of the verb are present in Vulgata $^{37}$, both with its proper and figurative meaning; and it is used as such by the most famous Latin Christian writers: Tertullianus ( 4 occ.), Cyprianus ( 2 occ.), Ambrosius (23 occ.), Augustinus (over 100 occ.), Hieronymus (17 occ.), etc. The definition of the word enriches over time, due to the latter authors: "to burn (a martyr), to burn (as sacrifice), to lit (candles) or to illuminate (a translation)" (see Blaise, 1993, s.v. incendo).

Common throughout Latinity, and on different levels of the language, incendere should not be linked to the spoken aspect of communication.

\subsection{DRACO}

With the meaning 'devil', the word continued in few of the Romance languages ${ }^{38}$, but, in Latin, as 'devil, Fr. diable', draco appears in Vulgata, and at the most important Christian writers, beginning with Tertullianus $\left(2^{\text {nd }}-3^{\text {rd }}\right.$ century) (Blaise, 1993, s.v. draco, -onis, 2. 'le dragon, le diable')—who, as the first Christian writer in Latin, lays the foundations of the Latin Christian vocabulary, at least in writing. In Ad uxorem, when he writes about ipso dracone $(1,6,12)$, he refers to draco ille magnus from Revelation, 12, 9 and 20, 2, translated into Romanian as "balaur" (Engl. lit. dragon), but understood as 'the devil', and 'the Satan'39.

Augustinus explains the passage in Psalms, 90,14 as a direct reference to the devil: de diabolo dictum est: et conculcabis leonem et draconem (Adnotationes in Iob 38, 615, 2) "about the devil it was said: 'and you will trample over the lion and the devil'". Hieronymus is even more explicit when shows that draco is translated in different ways by the Hebrews and the Greeks, and states its equivalence with satan and diabolus: In die illa inducet deus gladium sanctum [...] et occidet draconem qui est in mari. Tradunt hebrei diabolum, id est criminatorem, quod grecum nomen est, hebraice appellari satan, hoc est aduersarium. (Commentarii in Isaiam 8, 27, 1, 4) "That day God will lead the holy sword [...] and will kill the dragon that's in the sea. The Jews translate: the devil, which means the accuser, which is a Greek word. In Hebrew, it's called Satan, which is the hostile one".

\footnotetext{
35 "La lune embrasée par les rayons du soleil" (Gaffiot, 2000, s.v. incendo).

36 "La lune qu’allument les rayons du soleil" (Gaffiot, 2000, s.v. accendo).

${ }^{37}$ See also incendit ignem "stir up the fire" (Ecclesiasticus, 28, 13; 23, 23).

38 "Cuvântul draco-onis, care desemna "dragonul” (un șarpe mitic), a căpătat numai pe teritoriul de limbă latină din care se va dezvolta româna, albaneza și provențala sensul 'drac'” [The word draco, -onis, that used to designate 'the dragon' (a mythical serpent), has developed the meaning 'devil' only on the areas of Latin where Romanian, Albanian and Provençal would emerge.] (Ivănescu, 2000, p. 173-174).

${ }^{39}$ Rev , 12, 9: "Și aruncat a fost Balaurul cel mare, șarpele cel de demult, care se cheamă diavol și Satana [...]” (Anania, 2001, p. 1763) [“And the great dragon was cast out, that old serpent, called the Devil, and Satan", KJv]; Rev, 20, 2: "Și l-a prins pe Balaur, pe șarpele cel vechi, care este diavolul și Satana [...]" (Anania, 2001, p. 1770) ["And he laid hold on the dragon, that old serpent, which is the Devil, and Satan..., kJv].
} 
It follows that the meaning 'devil' of the word draco, -onis must not be connected to the people's Latin, but to the Late Christian Latin. The fact that it is employed in biblical texts and that it is employed with the meaning 'devil' by most of the Christian writers proves that its use is not a characteristic of the language spoken by uneducated people; it must be related to the semantic neologisms of the Christian period, namely to the new meanings given by Christians to old words.

\section{Conclusions}

Studying the Latin attestation of the terms that continued into Romance languages, the researcher is able to observe their dynamics on different levels of the Latin language, and in different periods of time. Naturally, the evolution of such a word led to the change of the signifier, as shown on the basis of the phonetical laws. Our approach did not concern the identification of the various forms that these words had appeared with, in various texts, but the attestation of these words in written literature (Archaic, Classical, and Christian), in order to understand if and to what extent was a word-which is believed to have belonged to the spoken Latin-current in the literary Latin of a particular period.

By dint of our analysis, we conclude that, if a word belongs to the spoken Latin and also to its written variant (because the writing only is in the position to present a variant of the spoken, common language), the word in question belongs in fact to a common stock of terms that cannot be seen as characterizing exclusively one or the other level of the language. These words belong both to the spoken Latin, and to the Classical, written Latin; to the Latin of the Archaic and Classical period, and to the Latin of the Late period; they are known and used by cultivated (educated) people, as well as by uneducated, even illiterate people. The fact that there are and function, in parallel, during all epochs, (partial) synonyms: casa vs. domus, formosus vs. bellus, uetulus vs. senex, auricula vs. auris, gula vs. os, manducare vs. edere, incendere vs. accendere is a strong argument for the idea that the etymons of the majority of the Latin words inherited by the Romance belong to a common Latin stock.

This common stock is subordinated to the idea of a common language, a 'common Latin', as Maria Iliescu puts it: "Pour chaque moment de l'histoire du latin on a la possibilité de concevoir un latin commun qui inclut le latin littéraire (écrit et parlé), le latin des couches moyennes, le latin parlé dans les milieux rustiques, le latin parlé par les locuteurs des régions italiques” (Iliescu, 2013, p. 141) ) $^{40}$ The expression was used by Coșeriu (1954), to whom 'Vulgar Latin' may identify with the 'common language' of the Roman Empire.

\section{Bibliography}

\section{A. References}

Coșeriu, E. (1954). El llamado “latín vulgar” y lasprimeras differenciaciones romances, Universidad de la Republica, Montevideo. Coșeriu, E. (1997). Sincronie, diacronie și istorie. Problema schimbării lingvistice, versiune în limba română de N. Saramandu, Editura Enciclopedică, București.

Coșeriu, E. (2005). Le latin vulgaire des romanistes, texte rédigé par Benjamín García-Hernández, în La variabilité en langue. Les quatre variations, „Studies in Language”, 6, p. 17-25.

Flobert, P. (2014). Le mythe du latin dit «vulgaire », în Grammaire comparée et variétés du latin. Articles revus et mis à jour (1964-2012), Librairie DROZ, Genève (articol publicat în prima variantă în 1998).

Grandgent, C.H. (1907). An Introduction to Vulgar Latin, D. C. Heath \& Co., Boston.

Haadsma, R. A. \& Nuchelmans, J. (1963). Précis de latin vulgaire, J. B. Wolters, Gröningen.

Herman, J. (1967). Le latin vulgaire, Presses Universitaires de France, Paris.

Iliescu, M. (2013). Le soi-disant 'latin vulgaire' et les premières différentiations dans la Romania (Coseriu 1954) et l'état actuel de la question, în Bojoga, E., Boc, O. \& Vîlcu, D.C. (eds), Coseriu: Perspectives contemporaines, Actes du deuxième Colloque International d'études cosériennes CoseCluj 2009, 23-25 septembre, Cluj-Napoca, Roumanie, Tome 1, Presa Universitară Clujeană, p. 137-145.

\footnotetext{
40 "For every moment in the history of Latin we have the possibility to think of a common Latin which encompasses the literary Latin (written and spoken), the Latin of the middle classes, the Latin spoken in rural milieus, the Latin spoken by the inhabitants of the Italic regions".
} 
Ivănescu, G. (2000). Istoria limbii române, ediția a II-a, îngrijirea ediției, indice de autori și indice de cuvinte: Mihaela Paraschiv, Editura Junimea, Iași.

Väänänen, V. (1981). Introduction au latin vulgaire, $3^{\text {ème }}$ édition revue et augmentée, Klincksieck, Paris.

\section{B. Sources}

Anania (2001). Biblia sau Sfinta Scriptură, București, [versiune diortosită după Septuaginta, redactată și adnotată de Bartolomeu Valeriu Anania Arhiepiscopul Clujului], Editura Institutului Biblic și de Misiune al Bisericii Ortodoxe Române.

Blaise, A. (1993). Dictionnaire latin-français des auteurs chrétiens, revu spécialement pour le vocabulaire théologique par Henri Chirat, Brepols (édition originale 1954).

Bloch, R. (1981). Pline l'Ancien, Histoire naturelle, XXXVI, texte établi par J. André, trad. par R. Bloch, commenté par A. Rouveret, Belles Lettres, Paris.

CLTCLT-5 = CETEDOC Library of Christian Latin Texts, Universitas Catholica Lovaniensis Lovanii Novi, Brepols, 2002.

Ernout, A. (1992). Plaute, Comédies, tome IV, Menaechmi, Mercator, Miles gloriosus, texte établi et traduit par Alfred Ernout, Belles Lettres, Paris.

Gaffiot, F. (2000). Le Grand Gaffiot. Dictionnaire latin-français, nouvelle édition revue et augmentée sous la direction de Pierre Flobert, Hachette, Paris.

$\mathrm{KJV}=$ The Holy Bible. (...), World Bible Publishers, Inc., [s.l.], [s.a.].

Marouzeau, J. (1990). Térence, Comédies, tome II : Heautontimorumenos, Phormion, texte établi et traduit par J. Marouzeau, Belles Lettres, Paris.

Septuaginta I = Septuaginta. Geneza, Exodul, Leviticul, Numerii, Deuteronomul, volum coordonat de Cristian Bădiliță, Francisca Băltăceanu, Monica Broșteanu, Dan Slușanschi în colaborare cu pr. Ioan-Florin Florescu, Polirom, s.l., 2004.

Septuaginta [IV] = Septuaginta. Psalmii, Odele, Proverbele, Ecleziastul, Cîntarea Cântărilor, volum coordonat de Cristian Bădiliță, Francisca Băltăceanu, Monica Broșteanu în colaborare cu pr. Ioan-Florin Florescu, traduceri de Cristian Bădiliță, Francisca Băltăceanu, Florica Bechet ș.a., Polirom, s.l., 2006.

Septuaginta IV/2 = Septuaginta. Iov, Ințelepciunea lui Solomon, Ințelepciunea lui Iisus Sirah, Psalmii lui Solomon, volum coordonat de Cristian Bădiliță, Francisca Băltăceanu, Monica Broșteanu în colaborare cu pr. Ioan-Florin Florescu, traduceri de Smaranda Bădiliță, Francisca Băltăceanu, Monica Broșteanu ș.a., Polirom, s.l., 2007.

тов = Ancien Testament, traduction œcuménique de la Bible, édition intégrale, 99e mille, Cerf/Les Bergers et les Mages, Paris, 1979.

Viarre, S. (2005). Properce, Elegies, texte établi, trad. et commenté par Simonne Viarre, Belles Lettres, Paris.

[Translated by Adina Chirilă] 